14 Boyd RV, Hawthorne J, Wallace WA, Worlock PH, Crompton EH. The Nottingham orthogeriatric unit after 1000 admissions. Injury 1983;15: 193-6

15 Taggart HM. Geriatric-orthopaedic rehabilitation in Belfast. In: Caird FI. Evans JG eds. Adoanced geriaric medicine 3. London: Pirman, 1983:144.50.

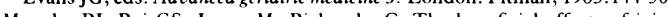
(1987:16:273-8.

17 Smith DL. The elderly in the convalescent orthopaedic trauma ward: can the geriatrician help? Health Bull (Edinb) 1984:42:36-45.

18 Burley LE, Scorgie RE, Currie CT, Smith RG, Williamson J. The joint geriatric orthopaedic service in South Edinburgh. Health Bull (Edinb) $1984 ; 42: 133-40$

19 Fordham R, Thompson R, Holmes J, Hodkinson C. A cost-benefit study of geriatric-orthopaedic management of patients with fractured neck of femur. York: University of York, 1986. (Centre For Health Economics discussion paper 14.

20 Harrington MG, Brennant M, Hodkinson HM. The first year of a geriatricorthopaedic liaison service: an alternative to 'orthogeriatric' units? Age Ageing 1988;17:129-33.

$21 \mathrm{Katz}$ S, Ford AB, Moskowitz RW, Jackson BA, Jaffe MW. Studies of illness in the aged: the index of ADL: a standardized measure of biological and the aged: the index of ADL: a standardized

22 Pfeifer E. A shor porable mental stats que organic brain deficit in elderly patients. $f$ Am Geriatr Soc 1975;23:433-41.
23 Jensen JS, Bagger J. Long term social prognosis after hip fractures. Actu Orthop Scand 1982;53:97-101.

24 Tukey JW. Exploratory data analysis. Reading, Massachusetts: AddisonWesley, 1977 .

25 Pryor GA, Myles JW, Williams DRR, Anand JK. Team management of the elderly patient with hip fracture. Lancet 1988;i:401-3.

26 Department of Health and Social Security. Orthopaedic services: waiting time for out-patient appointments and inpatient treatment. Report of a working party 10 the Secretary of State for Social Services. London: HMSO, 1981

27 Robbins JA, Donaldson LJ. Analysing stages of care in hospital stay for fractured neck of femur. Lancet 1984;ii: 1028-9.

28 Orem DE. Nursing: concepts of practice. New York: McGraw-Hill, 1980

9 Villar RN, Allen SM, Barnes SJ. Hip fractures in healthy patients: operative delay versus prognosis. Br Med f 1986;293:1203-4.

30 McLaren AD, Stockwell MC, Reid VT. Anaesthetic techniques for surgical correction of fractured neck of femur: a comparative study of spinal and general anaesthesia in the elderly. Anaesthesia 1978;33:10-4.

31 Burnett JW, Gustilo RB, Williams DN, Kind AC. Prophylactic antibiotics in hip fractures: a double-blind, prospective study. F Bone foint Surg [Am] 1980;62:457-62.

32 Wolfe JHN. Postphlebitic syndrome after fractures of the leg. $\mathrm{Br}$ Med $\mathrm{J}$ $1987 ; 295: 1364-5$.

(Accepted 8 September 1988)
Hvidöre Hospital, DK-2930 Klampenborg, Denmark Hans-Henrik Parving, MD, chief physician

Eva Hommel, MD, registrar Ulla M Smidt, laboratory technician

Correspondence to: $\mathrm{Dr}$ Parving.

\title{
Protection of kidney function and decrease in albuminuria by captopril in insulin dependent diabetics with nephropathy
}

\author{
Hans-Henrik Parving, Eva Hommel, Ulla M Smidt
}

\begin{abstract}
Study objective-To assess whether long term inhibition of angiotensin converting enzyme with captopril and frusemide or bendrofluazine protects kidney function in diabetic nephropathy.

Design-Non-randomised controlled before-after trial of matched hypertensive insulin dependent diabetics with nephropathy treated with captopril and frusemide or bendrofluazide.
\end{abstract}

Setting-Outpatient diabetic clinic in tertiary referral centre.

Patients-Treatment group of 18 hypertensive insulin dependent diabetics with nephropathy (mean age 33), who had not been treated previously. Control group of 13 patients (mean age 32 ) fulfilling the same entry criteria from a prospective study

Interventions - Treatment group was given daily captopril $37 \cdot 5-100 \cdot 0 \mathrm{mg}$ and frusemide (mean) $98 \mathrm{mg}$ (10 patients) or bendrofluazide (mean) $4 \mathrm{mg}$ (seven). Treatment was continued for about two and a half years. Controls were not treated.

End point-Measurement of arterial blood pressure, albuminuria, and glomerular filtration

Measurements and main results-Baseline values were identical in treated and untreated groups respectively: mean blood pressure 146/93 (SE 3/1) mm Hg $v$ 137/95 (2/1) mm Hg; geometric mean albuminuria 982 (antilog SE 1.2) $\mu \mathrm{g} / \min v 936(1.2)$ $\mu \mathrm{g} / \mathrm{min}$; and mean glomerular filtration rate 98 (SE 5) $\mathrm{ml} / \mathrm{min} / 1.73 \mathrm{~m}^{2} v 96(6) \mathrm{ml} / \mathrm{min} / 1.73 \mathrm{~m}^{2}$. Mean arterial blood pressure fell by $8.7(1.3) \mathrm{mm} \mathrm{Hg}$ with captopril and rose by $6.6(1.5) \mathrm{mm} \mathrm{Hg}$ in controls, $(\mathrm{p}<0.001)$; Albumin excretion decreased to $390(1 \cdot 1) \mu \mathrm{g} / \mathrm{min}$ with captopril and rose to $1367(1.3) \mu \mathrm{g} / \mathrm{min}$ in controls $(p<0.001)$. The rate of decrease in glomerular filtration rate was lower with captopril $(5.8(0.7)$ $\mathrm{ml} /$ year $v 10.0(1.3) \mathrm{ml} /$ year $)(\mathrm{p}<0.01)$. Rate of fall in glomerular filtration rate and mean arterial blood pressure were significantly correlated $(n=31, r=0.37$, $\mathbf{p}<0.05$ )

Conclusions-Captopril is a valuable new drug for treating hypertension in insulin dependent diabetics with nephropathy.

\section{Introduction}

Renal failure due to diabetic nephropathy is the main cause of death in patients with insulin dependent diabetes, ${ }^{12}$ and on average death occurs seven years after the start of persistent albuminuria. ${ }^{13}$ Increased arterial pressure is an early and common occurrence in diabetic nephropathy. ${ }^{4}$ Systemic hypertension when transmitted to the glomerular capillary network results in glomerular capillary hypertension, ${ }^{5}$ which has also been shown in normotensive rats with diabetes that had been induced by streptozotocin. ${ }^{67} \mathrm{~A}$ link between glomerular hypertension and albuminuria and the development and progression of diabetic glomerulopathy has been suggested. ${ }^{89}$ In rats infusion of angiotensin II induced glomerular hypertension and albuminuria. ${ }^{10}$

We have shown that glomerular filtration rate is not dependent on angiotensin II and that inhibiting angiotensin converting enzyme with captopril for one week reduces albuminuria in hypertensive insulin dependent diabetics with nephropathy. "We present here our findings on the long term effect of captopril on glomerular filtration rate and albuminuria in such patients.

\section{Patients and methods}

\section{PATIENTS}

We examined the records of all patients with insulin dependent diabetes who had proteinuria (those positive on dipstick testing) who were visiting the outpatient clinic at this hospital during 1984. ${ }^{12}$ We invited all hypertensive patients to join the study if they were aged under 50; had persistent albuminuria $(>300 \mathrm{mg}$ albumin/day) and a serum creatinine concentration less than $120 \mu \mathrm{mol} / \mathrm{l}$ and no oedema; and developed diabetes before the age of 31 but were not receiving antihypertensive treatment (including diuretics) and were not blind. Twenty patients fulfilled these criteria and all gave fully informed consent. At the start of the study one patient was excluded because treatment with thiazides had been started for oedema. One man was excluded after nearly one year's investigation because a renal biospy showed mesangioproliferative glomerulonephritis superimposed on a diffuse diabetic glomerulosclerosis.

Eighteen patients were studied. Apart from the first three patients (cases 1-3), who initially received combined treatment with captopril and a diuretic, all the remaining 15 patients were initially included in a randomised controlled trial to investigate the effect of 
TABLE I-Clinical data on hypertensive insulin dependent diabetic patients with nephropathy

\begin{tabular}{|c|c|c|c|c|c|c|c|c|}
\hline Case No & Sex & $\begin{array}{c}\text { Age } \\
\text { (years) }\end{array}$ & $\begin{array}{c}\text { Duration of } \\
\text { diabetes } \\
\text { (years) }\end{array}$ & Retinopathy & $\begin{array}{l}\text { Mean dose } \\
\text { of insulin } \\
\text { (U/kg/day) }\end{array}$ & $\begin{array}{l}\text { Mean body } \\
\text { mass index } \\
\left(\mathrm{kg} / \mathrm{m}^{2}\right)\end{array}$ & $\begin{array}{l}\text { Mean energy } \\
\text { intake } \\
(\mathrm{MJ} / \text { day })\end{array}$ & $\begin{array}{l}\text { Antihypertensive treatment } \\
\text { (dose in mg/day) }\end{array}$ \\
\hline \multicolumn{9}{|c|}{ Patients treated with captopril } \\
\hline 1 & $\mathrm{~F}$ & 40 & 28 & Proliferative & 0.54 & $20 \cdot 5$ & $6 \cdot 0$ & Captopril 100 , frusemide 80 \\
\hline 2 & $\mathrm{M}$ & 37 & 16 & Proliferative & 0.52 & 21.9 & $10 \cdot 0$ & Captopril 100 , frusemide 40 \\
\hline 3 & $\mathrm{~F}$ & 29 & 13 & Simplex & 0.64 & $24 \cdot 3$ & $8 \cdot 0$ & Captopril 100 , frusemide 80 \\
\hline 4 & $M$ & 43 & 20 & Proliferative & $0 \cdot 49$ & $24 \cdot 6$ & $8 \cdot 8$ & Captopril 100 , bendrofluazide 5 \\
\hline 5 & $M$ & 34 & 18 & Proliferative & 0.55 & $23 \cdot 9$ & $9 \cdot 2$ & Captopril 100 , frusemide 40 \\
\hline 6 & $M$ & 46 & 20 & Proliferative & 0.63 & $23 \cdot 9$ & $8 \cdot 0$ & Captopril 75, frusemide 160 \\
\hline 7 & $M$ & 30 & 20 & Proliferative & $0 \cdot 41$ & $23 \cdot 1$ & $10 \cdot 0$ & Captopril 100 , bendrofluazide 2.5 \\
\hline 8 & M & 24 & 15 & Simplex & $0 \cdot 80$ & $20 \cdot 7$ & $10 \cdot 0$ & Captopril 100 , bendrofluazide 2.5 \\
\hline 9 & $\mathrm{M}$ & 29 & 15 & Proliferative & 0.49 & $25 \cdot 2$ & $9 \cdot 0$ & Captopril 100 , bendrofluazide 10 \\
\hline 10 & $M$ & 31 & 27 & Proliferative & 0.80 & $24 \cdot 6$ & $8 \cdot 0$ & Captopril 100 , frusemide 80 \\
\hline 11 & $\mathrm{M}$ & 19 & 13 & Simplex & 0.96 & $22 \cdot 7$ & $13 \cdot 3$ & Captopril 100 , bendrofluazide 2.5 \\
\hline 12 & $\mathrm{M}$ & 34 & 28 & Proliferative & 0.62 & $24 \cdot 0$ & $9 \cdot 0$ & Captopril 50 , frusemide 120 \\
\hline 13 & $M$ & 26 & 19 & Proliferative & 0.75 & $21 \cdot 5$ & $10 \cdot 0$ & Captopril 100 , frusemide 160 \\
\hline 14 & $\mathrm{~F}$ & 25 & 18 & Simplex & 0.42 & 21.9 & $6 \cdot 3$ & Captopril 100 , frusemide 40 \\
\hline 15 & $\mathrm{M}$ & 43 & 20 & Proliferative & 0.67 & $23 \cdot 3$ & $11 \cdot 0$ & Captopril 100 , bendrofluazide 2.5 \\
\hline 16 & $\mathrm{~F}$ & 23 & 22 & Simplex & 0.53 & $21 \cdot 9$ & $5 \cdot 0$ & Captopril 50, frusemide 40 \\
\hline 17 & $M$ & 30 & 17 & Simplex & 0.50 & $26 \cdot 6$ & $10 \cdot 4$ & Captopril 75 , bendrofluazide 5 \\
\hline 18 & $M$ & 46 & 42 & Simplex & 0.56 & $25 \cdot 8$ & $9 \cdot 0$ & Captopril 75 \\
\hline \multicolumn{2}{|l|}{$\operatorname{Mean}(\mathrm{SE})$} & $33(2)$ & $21(2)$ & & $0.60(0.03)$ & $23.4(0.4)$ & $9 \cdot 0(0 \cdot 4)$ & \\
\hline & & & & & Controls & & & \\
\hline 19 & M & 40 & 21 & Proliferative & 0.61 & $21 \cdot 6$ & $8 \cdot 4$ & \\
\hline 20 & $M$ & 34 & 12 & Simplex & 0.44 & $22 \cdot 8$ & $9 \cdot 2$ & \\
\hline 21 & $M$ & 35 & $\cdot 6$ & None & $0 \cdot 28$ & $22 \cdot 6$ & $8 \cdot 4$ & \\
\hline 22 & $\mathbf{F}$ & 20 & 16 & Proliferative & 0.67 & $24 \cdot 4$ & $7 \cdot 1$ & \\
\hline 23 & $M$ & 28 & 27 & Proliferative & 0.62 & $22 \cdot 5$ & $8 \cdot 4$ & \\
\hline 24 & $M$ & 34 & 22 & Proliferative & 0.83 & $22 \cdot 8$ & $8 \cdot 0$ & \\
\hline 25 & $\mathrm{~F}$ & 28 & 17 & Simplex & $0 \cdot 73$ & $22 \cdot 2$ & $8 \cdot 8$ & \\
\hline 26 & $\mathrm{~F}$ & 19 & 8 & Simplex & $1 \cdot 25$ & $20 \cdot 0$ & $8 \cdot 4$ & \\
\hline 27 & F & 34 & 19 & Proliferative & $0 \cdot 70$ & $21 \cdot 4$ & $7 \cdot 2$ & \\
\hline 28 & $M$ & 35 & 19 & Proliferative & 0.58 & $24 \cdot 1$ & $10 \cdot 0$ & \\
\hline 29 & M & 37 & 22 & Proliferative & 0.60 & $24 \cdot 2$ & $10 \cdot 5$ & \\
\hline 30 & M & 37 & 16 & Simplex & 0.65 & $25 \cdot 6$ & $10 \cdot 5$ & \\
\hline 31 & M & 36 & 13 & Simplex & 0.55 & $24 \cdot 8$ & $9 \cdot 2$ & \\
\hline Mean (SE) & & $32(2)$ & $17(2)$ & & $0.65(0.06)$ & $23 \cdot 0(0 \cdot 4)$ & $8 \cdot 8(2 \cdot 9)$ & \\
\hline
\end{tabular}

treatment with captopril alone on kidney function. ${ }^{11}$ After baseline investigation between December 1984 and April 1985 treatment with captopril and frusemide or a thiazide was started in all 18 patients (table I). With the antihypertensive treatment we aimed at achieving a stable reduction in diastolic blood pressure to below $90 \mathrm{~mm} \mathrm{Hg}$ and of at least $10 \mathrm{~mm} \mathrm{Hg}$ in mean arterial blood pressure (diastolic pressure plus one third of the pulse amplitude), or both.

From 1976 to 1983 we had prospectively studied the initial clinical course of diabetic nephropathy in 24 patients with insulin dependent diabetes, none of whom received treatment apart from insulin. ${ }^{13}$ Sixteen patients had hypertension (diastolic blood pressure $\geqslant 90 \mathrm{~mm} \mathrm{Hg}$ ), but only the 13 patients who fulfilled exactly the inclusion criteria described above served as an untreated control group in this study (table I). Raised serum creatinine concentration was the reason for excluding the remaining three hypertensive patients, whose glomerular filtration rate decreased by a mean of $9.6(\mathrm{SE} 2.4) \mathrm{ml} / \mathrm{min} /$ year.

All patients in both groups were dependent on insulin from the time of diagnosis, and all received at least two daily injections of highly purified porcine insulin. They had a normal diabetic diet containing $45-$ $55 \%$ carbohydrate, $30-35 \%$ fat, and $15-20 \%$ protein throughout the study. None of the patients had their intake of salt or protein restricted. Hypertension was diagnosed if the mean of the last three measurements performed in the outpatient clinic before the start of the study was equal to or greater than $160 / 90 \mathrm{~mm} \mathrm{Hg}$. Nephropathy was diagnosed clinically according to previously described criteria. ${ }^{14}$ One control patient (case 21) with diabetes of less than 10 years' duration did not have retinopathy. A kidney biopsy was therefore performed, and diffuse diabetic glomerulosclerosis was found with no other lesion.

\section{METHODS}

All investigations were carried out on one day between 0830 and 1300 . Patients had their normal breakfast and morning dose of insulin before the investigations, during which they rested supine and stood up only to pass urine. They drank $150-200 \mathrm{ml}$ tap water/hour during the study. The investigations were carried out six to eight times during 27-36 (mean 31) months in the treated group and four to 13 (mean eight) times during 23-66 (mean 33) months in the untreated group. The untreated group was investigated every six months whereas the treated group was studied after one week, after three months, and then every six months.

To measure the glomerular filtration rate we gave the patients a single intravenous injection of edetic acid labelled with $37 \mathrm{MBq}$ sodium chromate-51 at 0900 and determined the radioactivity in plasma from samples of venous blood taken from the other arm 180, 200, 220, and 240 minutes after the injection. ${ }^{15}$ The results were standardised for $1.73 \mathrm{~m}^{2}$ body surface area, using the patients' surface area at the start of the study. The mean coefficient of variation in the glomerular filtration rate of each patient from day to day was $4 \%$.

Urinary albumin excretion was measured during the four hour clearance period by radioimmunoassay in the treated group ${ }^{16}$ and by radial immunodiffusion in the untreated group. ${ }^{17}$ The assays had a sensitivity of 0.5 $\mathrm{mg} / \mathrm{l}$ and $2 \mathrm{mg} / \mathrm{l}$, respectively, and a coefficient of variation between assays of $9 \%$ and $8 \%$, respectively. Albumin concentration was measured simultaneously by both methods in urine collected from 27 of the patients with insulin dependent diabetes. The urinary albumin excretion rate ranged from $19 \mu \mathrm{g} / \mathrm{min}$ to 4860 $\mu \mathrm{g} / \mathrm{min}$ (median $599 \mu \mathrm{g} / \mathrm{min}$ ), and the results of both methods showed a close relation $(y=0.98 \times-2$; $r=0.98$, where $y$ and $x$ represent the albumin concentration determined with immunodiffusion and radioimmunoassay, respectively). Urinary sodium excretion was measured during the four hour clearance period with conventional laboratory techniques.

Blood pressure was measured with a standard clinical mercury sphygmomanometer (cuff $25 \times 12$ $\mathrm{cm}$ ) on the right arm. It was taken at least twice during each investigation between 0900 and 1000 and between 1200 and 1300 and at each visit to the outpatient clinic 
(between 1400 and 1600) after the patient had been supine for 10 minutes or more. Diastolic blood pressure was recorded at the disappearance of the Korotkoff sounds (phase V).

Blood glucose concentration was measured hourly during the four hour clearance period and at each visit to the clinic by a glucose oxidase method. Serum albumin, electrolyte, and cholesterol concentrations and leucocyte counts were measured by conventional laboratory techniques during each investigation only in the treated group. Stable haemoglobin $\mathrm{A}_{\mathrm{lc}}$ concentration was measured only in the treated group (normal range $4 \cdot 1-6 \cdot 1 \%$ of total haemoglobin. ${ }^{18}$

All of the 18 treated patients collected urine for one 24 hour period every six months for measuring the excretion of urea. This was used to calculate protein intake from the nitrogen content of the urea and an estimated value of non-urea nitrogen of $31 \mathrm{mg} / \mathrm{kg} /$ day ${ }^{19}$ (Assuming a constant nitrogen balance, nitrogen intake = nitrogen content of urinary urea plus nonurea nitrogen; protein intake $(\mathrm{g} /$ day $)=$ nitrogen intake $\times 6 \cdot 25 .{ }^{20}$

All patients visited the clinic every two to four months during the investigation. At each visit the postprandial blood glucose concentration was measured along with urinary glucose excretion, blood pressure, and body weight, and the dose of insulin and antihypertensive treatment were adjusted. Ophthalmoscopy was carried out on dilated pupils at least every six to 12 months.

\section{STATISTICAL ANALYSIS}

Wilcoxon's non-parametric test for unpaired and paired comparisons (two tailed) was used. Urinary albumin excretion rates were logarithmically transformed before analysis because of their positively skewed distribution; the geometric mean (antilog SE) is given in table II. Linear regression analysis (least squares method) was used to assess the decrease in glomerular filtration rate, the rate of decrease being calculated from all values of glomerular filtration rate in each group. All values are given as means $(\mathrm{SE})$ and significance was taken as $\mathrm{p}<0 \cdot 05$.

\section{Results}

The two groups were well matched with respect to sex, age, duration of diabetes, retinopathy, insulin dose, body mass index, and energy intake (table I). Furthermore, baseline values for blood pressure, glomerular filtration rate, and albumin excretion (were similar in the two groups (table II); difference in mean arterial blood pressure $2 \mathrm{~mm} \mathrm{Hg}$ (95\% confidence interval -1 to 5 ); difference in glomerular filtration rate $2 \mathrm{ml} / \mathrm{min} / 1.73 \mathrm{~m}^{2}$ (-13 to 17 ); and ratio of albumin excretion in the treated to untreated group $1.05(-0.60$ to $1 \cdot 84)$ ). Mean arterial blood pressure decreased in 17 of the 18 patients treated with captopril, and mean albumin excretion decreased significantly in all patients $(\mathrm{p}<0.01$, table II). By contrast, albumin excretion rose significantly in 11 of the 13 untreated patients $(p<0.01)$ and arterial blood pressure showed the same trend, although this was not significant. Mean arterial blood pressure and mean albumin excretion were significantly reduced in the treated compared with the untreated group ( $<<0.001$, table II and fig 1$)$, and, more importantly, the decrease in glomerular filtration rate was significantly less in the treated than the untreated group $(5.8(\mathrm{SE} 0.9) \mathrm{ml} / \mathrm{min} /$ year and 10.0 (1.3) $\mathrm{ml} / \mathrm{min} /$ year, respectively; table II and fig 1 ). Furthermore, mean arterial blood pressure and the rate of decrease in glomerular filtration rate were significantly correlated (fig 2), but not when data were analysed separately for each of the two groups.

The mean postprandial blood glucose concentration during the study was nearly identical in the treated and

TABLE II-Course of arterial blood pressure, albumin excretion, and glomerular filtration rate with and without antihypertensive treatment with captopril for diabetic nephropathy

\begin{tabular}{|c|c|c|c|c|c|c|c|}
\hline \multirow[b]{2}{*}{ Case No } & \multirow[b]{2}{*}{$\begin{array}{c}\text { Period of } \\
\text { investigation } \\
\text { (months) }\end{array}$} & \multicolumn{3}{|c|}{ Mean baseline values } & \multicolumn{3}{|c|}{ Mean values during investigation } \\
\hline & & $\begin{array}{l}\text { Arterial } \\
\text { blood } \\
\text { pressure } \\
(\mathrm{mm} \mathrm{Hg})\end{array}$ & $\begin{array}{l}\text { Albumin } \\
\text { excretion } \\
(\mu \mathrm{g} / \mathrm{min})\end{array}$ & $\begin{array}{c}\text { Glomerular } \\
\text { filtration } \\
\text { rate } \\
\left(\mathrm{ml} / \mathrm{min} / 1 \cdot 73 \mathrm{~m}^{2}\right)\end{array}$ & $\begin{array}{l}\text { Arterial } \\
\text { blood } \\
\text { pressure } \\
(\mathrm{mm} \mathrm{Hg})\end{array}$ & $\begin{array}{l}\text { Albumin } \\
\text { excretion } \\
(\mu \mathrm{g} / \mathrm{min})\end{array}$ & $\begin{array}{l}\text { Decrease in } \\
\text { glomerular } \\
\text { filtration rate } \\
(\mathrm{ml} / \mathrm{min} / \text { year })\end{array}$ \\
\hline \multicolumn{8}{|c|}{ Patients treated with captopril } \\
\hline 1 & 36 & $151 / 89$ & 556 & 76 & $122 / 73$ & 27 & $4 \cdot 3$ \\
\hline 2 & 35 & $135 / 95$ & 816 & 81 & $128 / 86$ & 205 & $5 \cdot 9$ \\
\hline 3 & 32 & $146 / 92$ & 455 & 133 & $136 / 90$ & 114 & $2 \cdot 3$ \\
\hline 4 & 35 & $147 / 88$ & 1101 & 85 & $139 / 77$ & 284 & $3 \cdot 7$ \\
\hline 5 & 30 & $129 / 86$ & 1549 & 70 & $126 / 85$ & 1065 & 3.5 \\
\hline 6 & 34 & $158 / 92$ & 2238 & 82 & $156 / 80$ & 967 & $7 \cdot 9$ \\
\hline 7 & 33 & $164 / 94$ & 1677 & 93 & $144 / 88$ & 1289 & $7 \cdot 4$ \\
\hline 8 & 31 & $134 / 96$ & 745 & 104 & $133 / 90$ & 72 & $3 \cdot 2$ \\
\hline 9 & 33 & $155 / 94$ & 352 & 115 & $140 / 89$ & 309 & $0 \cdot 1$ \\
\hline 10 & 31 & $151 / 104$ & 1864 & 104 & $139 / 95$ & 1288 & $8 \cdot 6$ \\
\hline 11 & 29 & $141 / 92$ & 1489 & 134 & $131 / 90$ & 980 & $2 \cdot 9$ \\
\hline 12 & 27 & $133 / 90$ & 1628 & 79 & $135 / 86$ & 470 & $7 \cdot 9$ \\
\hline 13 & 30 & $129 / 93$ & 275 & 124 & $133 / 86$ & 258 & $13 \cdot 0$ \\
\hline 14 & 27 & $152 / 98$ & 626 & 135 & $133 / 88$ & 410 & $13 \cdot 7$ \\
\hline 15 & 29 & $161 / 102$ & 2097 & 91 & $138 / 90$ & 760 & $5 \cdot 3$ \\
\hline 16 & 27 & $154 / 100$ & 2588 & 77 & $126 / 84$ & 1154 & $9 \cdot 2$ \\
\hline 17 & 27 & $141 / 88$ & 168 & 96 & $136 / 82$ & 80 & 0.1 \\
\hline 18 & 27 & $156 / 85$ & 2946 & 89 & $146 / 79$ & 1850 & $4 \cdot 7$ \\
\hline $\operatorname{Mean}(\mathrm{SE})$ & $31(1)$ & $146 / 93(3 / 1)$ & $982(1 \cdot 2)^{\star}$ & $98(5)$ & $136 / 85(2 / 1)$ & $390(1 \cdot 1)^{\star}$ & $5 \cdot 8(0 \cdot 9)$ \\
\hline \multicolumn{8}{|c|}{ Controls } \\
\hline 19 & 25 & $142 / 92$ & 2367 & 76 & $170 / 105$ & 3229 & $3 \cdot 8$ \\
\hline 20 & 33 & $136 / 92$ & 786 & 108 & $151 / 98$ & 787 & $5 \cdot 3$ \\
\hline 21 & 25 & $128 / 98$ & 1038 & 90 & $148 / 108$ & 1149 & $10 \cdot 8$ \\
\hline 22 & 23 & $135 / 98$ & 699 & 115 & $143 / 101$ & 173 & $17 \cdot 5$ \\
\hline 23 & 23 & $142 / 97$ & 1020 & 64 & $153 / 98$ & 2209 & $7 \cdot 3$ \\
\hline 24 & 29 & $130 / 98$ & 1091 & 113 & $149 / 108$ & 1339 & $17 \cdot 0$ \\
\hline 25 & 25 & $140 / 94$ & 1079 & 69 & $138 / 95$ & 1864 & $14 \cdot 5$ \\
\hline 26 & 24 & $135 / 95$ & 730 & 127 & $138 / 106$ & 1473 & $16 \cdot 0$ \\
\hline 27 & 30 & $142 / 92$ & 1141 & 65 & $137 / 90$ & 839 & $9 \cdot 5$ \\
\hline 28 & 43 & $130 / 94$ & 1167 & 107 & $137 / 87$ & 2647 & $9 \cdot 6$ \\
\hline 29 & 45 & $146 / 92$ & 3912 & 89 & $147 / 90$ & 6174 & $5 \cdot 3$ \\
\hline 30 & 38 & $132 / 98$ & 533 & 96 & $144 / 92$ & 1134 & $4 \cdot 3$ \\
\hline 31 & 66 & $138 / 90$ & 392 & 126 & $133 / 90$ & 911 & $8 \cdot 9$ \\
\hline Mean (SE) & $33(3)$ & $137 / 95(2 / 1)$ & $936(1 \cdot 2)^{\star}$ & $96(6)$ & $145 / 98(3 / 2) \ddagger$ & $1367(1 \cdot 3)^{\star} \ddagger$ & $10 \cdot 0(1 \cdot 3) \dagger$ \\
\hline
\end{tabular}

${ }^{\star}$ Geometric mean (antilog SE). $\nmid \mathrm{p}<0.01, \neq \mathrm{p}<0.001$, treated $v$ untreated group. 
untreated groups $(10.2(0.5) \mathrm{mmol} / \mathrm{l}$ and $10.6(0.5)$ $\mathrm{mmol} / \mathrm{l}$, respectively). Haemoglobin $A_{1 \mathrm{c}}$ concentration remained unchanged in the treated group (fig 3 ). The diet and body weight of the patients were also unchanged in both groups; average protein intake was $1 \cdot 1$ $(0.07) \mathrm{g} / \mathrm{kg} /$ day in the treated patients. Serum concentrations of potassium, sodium, albumin, and cholesterol remained unchanged during treatment with captopril; the leucocytes count dropped initially but returned later to the pretreatment value (figs 3,4 ). Neutropenia was not observed. None of the 18 patients receiving captopril had rash, disturbance of taste, headache, fatigue, depression, nightmares, or sexual dysfunction. One patient had a dry cough, but this vanished after three to four months' treatment; the dose was not reduced. Initially, two patients suffered from orthostatic symptoms when a diuretic drug was added to the captopril. None of the patients had abnormally raised serum potassium concentrations. All 18 patients continued to receive captopril in combination with a diuretic drug.

\section{Discussion}

Our study showed that long term treatment with captopril and diuretics protected kidney function and reduced albuminuria in hypertensive insulin dependent diabetics with nephropathy. This finding confirms and extends those of Mogensen, ${ }^{21}$ Björck et $a l,{ }^{22}$ and our previous observations. ${ }^{1423}$ The natural course of diabetic nephropathy is characterised by a relentless decrease in glomerular filtration rate and a progressive rise in blood pressure and albuminuria, ${ }^{132124}$ as was also shown in our untreated control group.

The study was not a double blind randomised parallel control trial, which is the ideal design. Such a trial, however, can no longer be considered to be ethical in hypertensive insulin dependent diabetics with nephropathy because "self controlled" studies have reported a beneficial effect of antihypertensive treatment on kidney function in such patients. ${ }^{1421-23}$

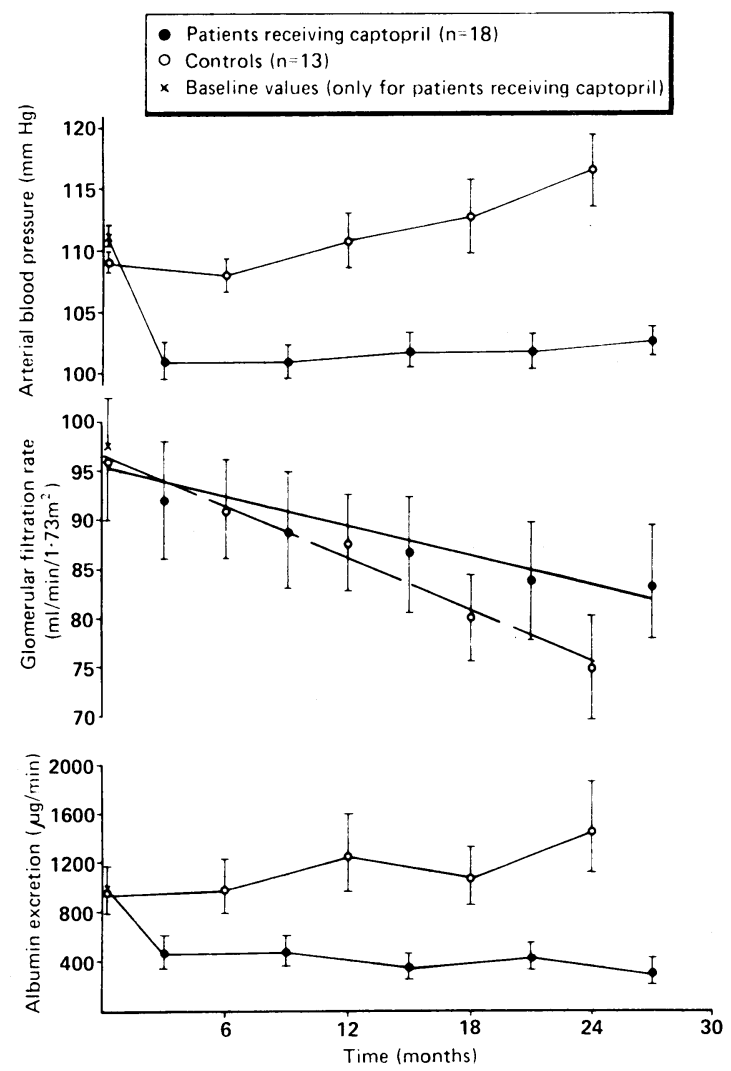

FIG 1-Mean course of mean arterial blood pressure, glomerular filtration rate, and albumin excretion in hypertensive insulin dependent diabetics with nephropathy during study. Bars are $S E$

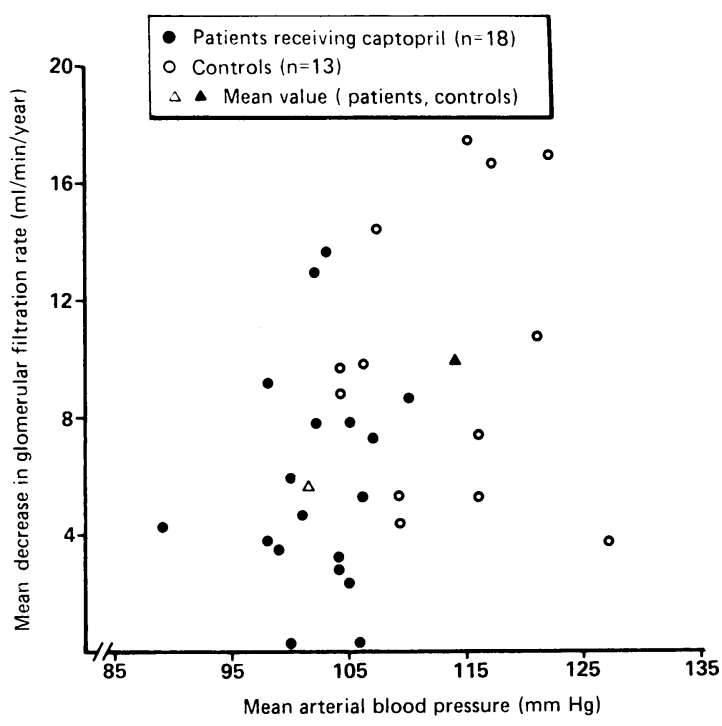

FIG 2-Relation between mean arterial blood pressure and decrease in glomerular filtration rate $(n=31, r=0.37, p<0.05)$
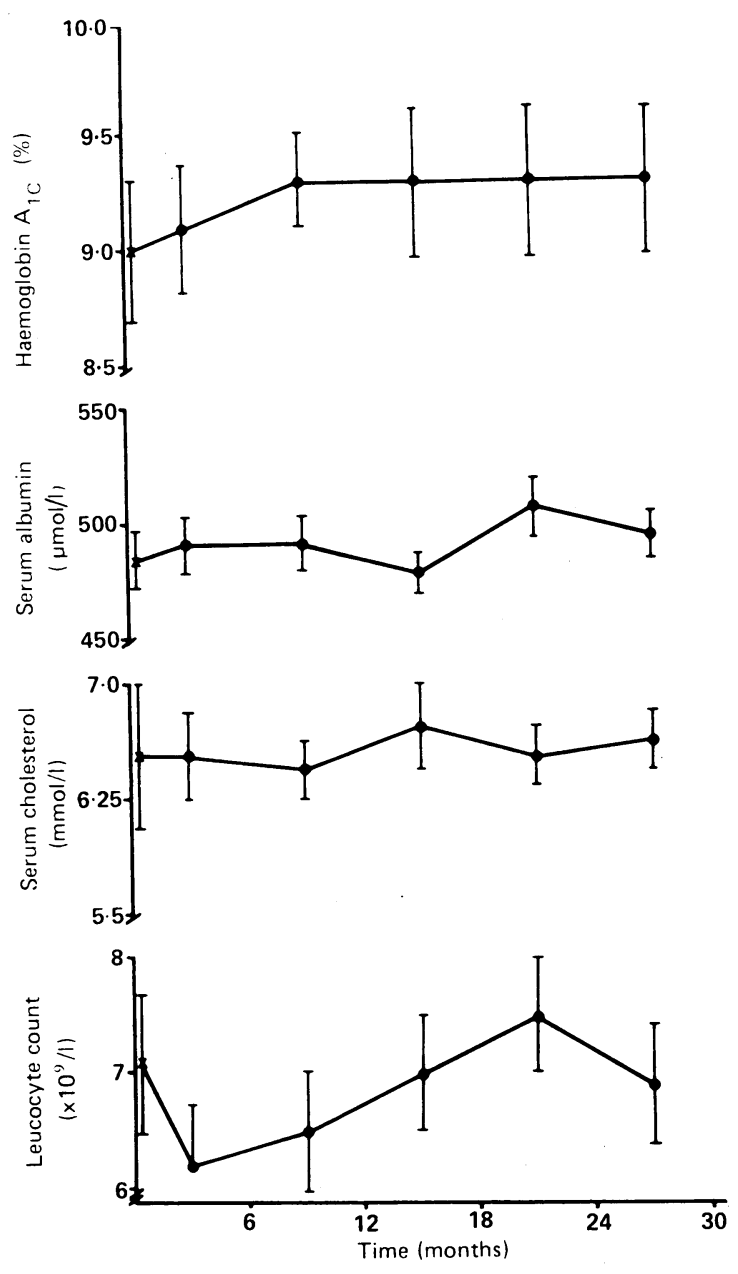

FIG 3-Mean course of mean haemoglobin $A_{I c}$, serum albumin, and serum cholesterol concentrations and leucocyte count before $(x)$ and during (O) treatment with captopril in 18 hypertensive insulin dependent diabetics with nephropathy. Bars are $S E$

We did, however, apply identical criteria for inclusion and exclusion of patients, which resulted in two well matched groups. Recommended energy intake and diet were about the same in both. Furthermore, intake of salt and protein was not restricted in either, and the urinary excretion of sodium (intake) was quite high in the group receiving captopril (fig 4). The average protein intake $(1.1 \mathrm{~g} / \mathrm{kg} /$ day $)$ in the treated group was nearly identical with the intake reported in insulin dependent diabetics with incipient and overt 

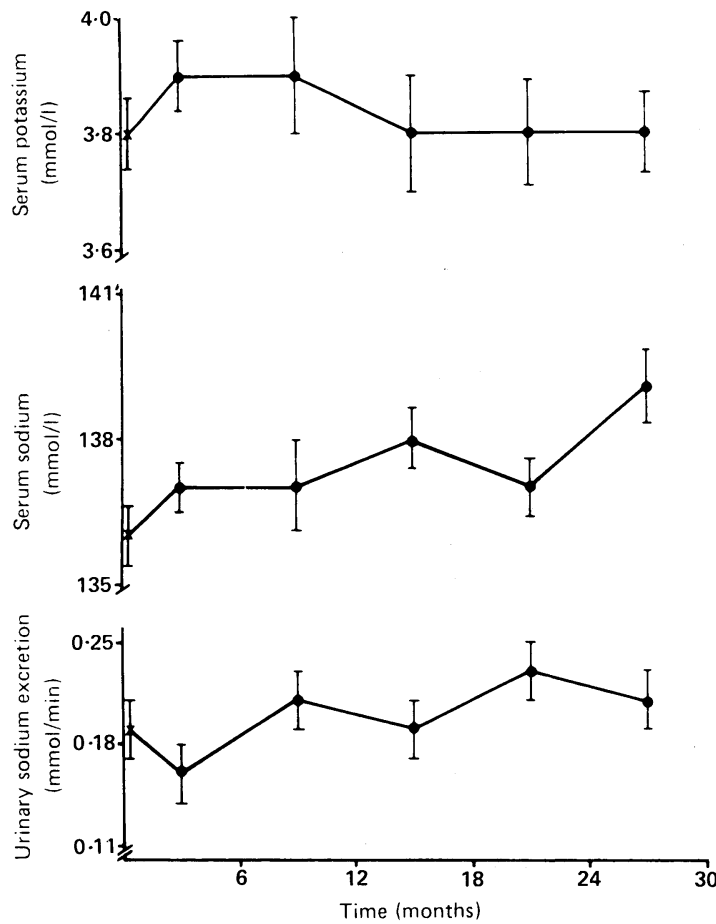

FIG 4-Mean course of mean serum potassium and sodium concentrations and urinary sodium excretion before $(x)$ and during $(\mathbf{0})$ treatmen with captopril in 18 hypertensive insulin dependent diabetics with nephropathy. Bars are SE

nephropathy taking normal diabetic diet $(1 \cdot 3 \mathrm{~g} / \mathrm{kg} /$ day and $1 \cdot 1 \mathrm{~g} / \mathrm{kg} /$ day, respectively). ${ }^{25}{ }^{26}$ Finally, the method used to determine glomerular filtration rate was identical in the two groups and the two techniques used for measuring urinary albumin concentration gave nearly the same result. These findings suggest that the comparison of the treated and untreated group is valid, though the possibility of a change in the natural course of the disease cannot entirely be ruled out.

Increased blood pressure is a common finding even early in the course of diabetic nephropathy. ${ }^{414}$ Sodium and water retention play a dominant part in initiating and maintaining hypertension in diabetic nephropathy, while the contribution from the renin-angiotensinaldosterone system is smaller. ${ }^{27} 28$ The predominant action of angiotensin II is confined to the efferent arteriole, thereby inducing increased pressure in the glomerular capillaries. ${ }^{29}$ Conversely, inhibition of angiotensin converting enzyme diminishes this pressure in animals ${ }^{30}$ and probably also in humans, as reflected by a drop in the filtration fraction. ${ }^{31}{ }^{32}$ In a one week randomised single blind trial of captopril versus placebo we showed that glomerular filtration rate in diabetic nephropathy was not dependent on angiotensin II and that captopril reduced albuminuria, probably by lowering glomerular hypertension. ${ }^{11}$ These findings led us to investigate the long term effect of a combined treatment with captopril and a diuretic in hypertensive insulin dependent diabetics with nephropathy.

Systemic and glomerular hypertension enhance al- buminuria and the development of diabetic glomerulopathy and accelerate the decrease in glomerular filtration rate in diabetic nephropathy ${ }^{89}{ }^{33-36}$ Systemic hypertension, when transmitted to the glomerular microcirculation, results in hypertension in the glomerular capillaries. Raised systemic blood pressure is accompanied by raised pressure in the glomerular capillaries in numerous experimental models of hypertensive renal disease (as reviewed by Anderson et al), ${ }^{5}$ including spontaneously hypertensive rats with diabetes that had been induced by streptozotocin. ${ }^{37}$ Increased pressure has even been shown in normotensive rats in which diabetes had been induced. ${ }^{67}$ Conversely, antihypertensive treatment with enalapril or restriction of dietary protein reduces glomerular hypertension and urinary albumin excretion and ameliorates the glomerular lesions induced by hypertension in diabetic animals. ${ }^{88}$ More importantly, antihypertensive treatment ${ }^{1421-23}$ and a low protein $\operatorname{diet}^{39}$ reduce albuminuria and protect kidney function in insulin dependent diabetic patients with nephropathy, as in the present study.

Our present and previous results suggest that albumin excretion largely depends on pressure, probably because of glomerular hypertension. ${ }^{1340}$ This suggestion has been supported by the finding of a significant correlation between the reduction in filtration fraction and the decrease in albuminuria during short term captopril treatment in diabetic nephropathy. ${ }^{32} \mathrm{~A}$ beneficial effect of enalapril on microalbuminuria has been shown in normotensive insulin dependent diabetic patients with incipient diabetic nephropathy ${ }^{41}$ The haemodynamic findings mentioned above strongly support the concept of Hostetter et al that hypertension is an important factor in the development and progression of diabetic glomerulopathy. ${ }^{8}$

Recent studies have shown that, unless pressure in the glomerular capillaries is reduced to near normal values, control of systemic hypertension is insufficient to prevent albuminuria and progressive glomerular injury in rats with reduced renal mass. ${ }^{5}$ Inhibition of angiotensin converting enzyme with enalapril was effective, though combined treatment with reserpine, hydralazine, and hydrochlorothiazide did not protect renal function, even though both treatment regimens induced the same reduction in systemic blood pressure. This finding led to the suggestion that all antihypertensive drugs are not equally effective in controlling progressive renal disease, which has been supported by the finding that inhibition of angiotensin converting enzyme was more beneficial to kidney function than conventional antihypertensive treatment in patients with renal diseases of different origin, ${ }^{31}$ including diabetic nephropathy. ${ }^{22}$ When the present results are compared with those obtained with selective $\beta$ blockers and diuretics no appreciable differences are apparent (table III). We emphasise, however, that selective $\beta$ blockers also reduce renin activity and angiotensin II concentration. Whether this beneficial effect on kidney function also applies to other types of hypotensive agents - for example, calcium entry blockers - remains to be elucidated.

An ideal antihypertensive drug regimen is charac-

TABLE III - Decrease in glomerular filtration rate in diabetic nephropathy with and without antihypertensive treatment in various studies

\begin{tabular}{|c|c|c|c|c|c|c|}
\hline \multirow[b]{2}{*}{ Investigators } & \multicolumn{2}{|c|}{ No of patients } & \multicolumn{2}{|c|}{ Mean (SE) blood pressure $(\mathrm{mm} \mathrm{Hg})$} & \multicolumn{2}{|c|}{$\begin{array}{l}\text { Mean (SE) decrease in glomerular filtration } \\
\text { rate }(\mathrm{ml} / \mathrm{min} / \text { year })\end{array}$} \\
\hline & Not treated & Treated & Not treated & Treated & Not treated & Treated \\
\hline Mogensen $^{21 \star} \dagger$ & 5 & 5 & $162 / 103(7 / 4)$ & $144 / 95(5 / 4)$ & $14 \cdot 8(4 \cdot 4)$ & $5.9(3.0)$ \\
\hline Parving et al $l^{1 \star \star} \dagger$ & 10 & 10 & $144 / 97(2 / 2)$ & $128 / 84(2 / 2)$ & $10 \cdot 9(1 \cdot 2)$ & $4.7(0.9)$ \\
\hline Parving et $a^{42 \star}$ & 8 & 8 & $150 / 100(3 / 3)$ & $131 / 87(3 / 2)$ & $10 \cdot 1(1 \cdot 4)$ & $4.8(1 \cdot 0)$ \\
\hline Present study & 13 & 18 & $145 / 98 \quad(3 / 2)$ & $136 / 85(2 / 1)$ & $10 \cdot 0(1 \cdot 3)$ & $5.8(0.9)$ \\
\hline
\end{tabular}

^Metoprolol, frusemide or thiazide, and hydralazine used as antihypertensive drugs. †Investigations conducted as "self controlled" trials. 
terised by effectiveness, safety, and maintenance of the quality of life. The present treatment was effective, and as the adverse effects were only minimal all patients continued to take it. The quality of life was less affected by the present treatment than by $\beta$ blockers with or without a diuretic. ${ }^{43}$ Previously $\beta$ blockers have been used commonly in hypertensive diabetics with ${ }^{1421}$ or without nephropathy ${ }^{+4}$ who were treated with insulin, even though these drugs mask some clinical signs of hypoglycaemia and prolong the recovery of blood glucose concentration after a hypoglycaemic attack. Patients being treated with insulin who lack warning signs of hypoglycaemia should, however, not be treated with $\beta$ blockers. These problems are absent during inhibition of angiotensin converting enzyme. ${ }^{45}$ In a comparative study captopril was found to be superior to different types of $\beta$ blockers in treating non-diabetic hypertensive patients with intermittent claudication, ${ }^{46}$ a finding of considerable clinical importance as peripheral vascular disease is an important problem in patients with diabetic nephropathy. Plasma lipid patterns have been shown not to be adversely affected during treatment with an inhibitor of angiotensin converting enzyme..$^{45}$ Finally, captopril can induce a shift to the left of the autoregulation curve of cerebral blood flow, ${ }^{47}$ a finding of potential importance in diabetics with hypertension when supine and hypotension when standing due to autonomic neuropathy.

In conclusion, inhibitors of angiotensin converting enzyme should be considered as first line drugs for treating hypertensive insulin dependent diabetics with nephropathy.

1 Deckert T, Poulsen JE, Larsen M. Prognosis of diabetics with diabetes onset before the age of thirty-one. I Survival, causes of death and complications. Diabetologia 1978:14:363-70.

2 Borch-Johnsen K, Andersen PK, Deckert T. The effect of proteinuria on relative mortality in type 1 (insulin-dependent) diabetes mellitus. Diabetologia 1985;28:590-6.

3 Andersen AR, Christiansen JS, Andersen JK, Kreiner S, Deckert T. Diabetic nephropathy in type 1 (insulin-dependent) diabetes: an epidemiological study. Diabetologia 1983:25:496-501.

4 Parving H-H, Andersen AR, Smidt UM, Oxenboll B, Edsberg B, Christiansen JS. Diabetic nephropathy and arterial hypertension. Diabetologia 1983;24 10-12.

5 Andersen S, Rennke HG, Brenner BM. Therapeutic advantage of converting enzyme inhibitors in arresting progressive renal disease associated with systemic hypertension in the rat. $\mathcal{F}$ Clin Invest 1986;77:1993-2000.

6 Hostetter TH, Troy JL, Brenner BM. Glomerular hemodynamics in experimental diabetes. Kidney Int 1981;19:410-5.

7 Jensen PK, Steven K, Blæhr H, Christiansen JS, Parving H-H. Effects of indomethacin on glomerular hemodynamics in experimental diabetes. Kidney Int 1986;29:490-5.

8 Hostetter TH, Rennke HG, Brenner BM. The case for intrarenal hypertension in the initiation and progression of diabetic and other glomerulopathies. Am f Med 1982;72:375-80.

9 Parving H-H, Viberti GC, Keen H, Christiansen JS, Lassen NA. Hemodynamic factors in the genesis of diabetic microangiopathy. Metabolism 1983:32:943-9.

10 Bohrer MP, Deen WM, Robertson CR, Brenner BM. Mechanism of angiotensin II induced proteinuria in the rat. Am $\mathcal{F}$ Physiol 1977;233: F13-21

11 Hommel E, Parving H-H, Mathiesen E, Edsberg B, Nielsen MD, Giese J. Effect of captopril on kidney function in insulin-dependent diabetic patient with nephropathy. BrMed f 1986;293:467-70.

12 Parving H-H, Hommel E, Mathiesen E, et al. Prevalence of microalbuminuria, arterial hypertension, retinopathy, and neuropathy in patients with insulin dependent diabetes. Br Med f 1988;296:156-60.

13 Parving H-H, Andersen AR, Hommel E, Smidt UM. Effect of antihypertensive treatment on diabetic nephropathy in insulin-dependent diabetic patients. In: Friedman EA, L'Esperance FA, eds. Diabetic renal-retinal syndrome. Vol In: Friedman EA, L'Esperance FA, eds. Diabetic
3. New York: Grune and Stratton, 1986:183-90.

14 Parving H-H, Andersen AR, Smidt UM, Svendsen PA. Early aggressive antihypertensive treatment reduces rate of decline in kidney function in diabetic nephropathy. Lancet 1983;i:1175-9.

15 Brochner-Mortensen J. A simple method for determination of glomerular filtration rate. Scand $\mathcal{F}$ Clin Lab Invest 1972;30:271-4.

16 Miles DW, Mogensen CE, Gundersen HJG. Radioimmunoassay for urinary albumin using a single antibody. Scand F Clin Lab Invest 1970;26:5-11.

17 Mancini G, Carbonara AO, Heremans JF. Immunochemical quantitation of antigens by single radial immunodiffusion. Immunochemistry 1965;2:235-54

18 Mortensen HB. Quantitative determination of haemoglobin $A_{1 c}$ by thin layer isoelectric focusing. $\mathcal{F}$ Chromatogr 1980;182:325-33.

19 Maroni BJ, Steinman TI, Mitch WE. A method for estimating nitrogen intake of patients with chronic renal failure. Kidney Int 1985;27:58-65.

20 Isaksson B. Urinary nitrogen output as a validity test in dietary surveys. $A m \mathcal{J}$ Clin Nutr 1980;33:4-5.

21 Mogensen CE. Long term antihypertensive treatment inhibiting progression of diabetic nephropathy. Br Med f 1982;285:685-8.

22 Biörck S, Nyberg G, Mulec H, Granerus G, Herlitz H, Aurell M. Beneficial effects of angiotensin converting enzyme inhibition on renal function in patients with diabetic nephropathy. Br Med $\mathcal{f}$ 1986;293:471-4

23 Parving H-H, Andersen AR, Smidt UM, Hommel E, Mathiesen ER Svendsen PA. Effect of antihypertensive treatment on kidney function in diabetic nephropathy. Br f Med 1987;294:1443-7.

24 Viberti GC, Bilous RW, Mackintosh D, Keen H. Monitoring glomerular function in diabetic nephropathy. Am f Med 1983;74:256-64.

25 Cohen D, Dodds R, Viberti GC. Effect of protein restriction in insulin dependent diabetics at risk of nephropathy. Br Med f 1987;294:795-8.

26 Nyberg G, Nordén G, Attman P-O, et al. Diabetic nephropathy: is dietary protein harmful? foumal of Diabetic Complications 1987;1:37-40.

27 O'Hare JA, Ferriss JB, Brady D, Twormey B, O'Sullivan DJ. Exchangeable sodium and renin in hypertensive diabetic patients with and without nephropathy. Hypertension 1985;7(suppl II):43-8.

28 Feldt-Rasmussen B, Mathiesen ER, Deckert T, et al. Central role for sodium in the pathogenesis of blood pressure changes independent of angiotensin, aldosterone and catecholamines in type 1 (insulin-dependent) diabetes mellitus. Diabetologia 1987;30:610-7

29 Myers BD, Deen WM, Brenner BM. Effects of norepinephrine and angiotensin II on the determinants of glomerular ultrafiltration and proximal tubule fluid reabsorption in the rat. Cir Res 1975;37:101-10.

30 Ichikawa J, Brenner BM. Glomerular actions of angiotensin II. Am f Med 1984;76:43-9.

31 Heeg JE, De Jong PE, Van der Hem GK, De Zeelew D. Reduction of proteinuria by

32 Elving LD, Wetzels JFM, De Nobel E, Hoitsma AJ, Borden JHM. Diabetic nephropathy: acute effects of captopril on renal haemodynamics and nephropathy: acute effects of captopril on renal

33 Berkman J, Rifkin H. Unilateral nodular diabetic glomerulosclerosis (Kimmelstiel-Wilson). Report of a case. Metabolism 1973;22:15-22.

34 Mauer SM, Steffes MW, Azar S, Sandberg SK, Brown DM. The effect of Mauer SM, Steffes MW, Azar S, Sandberg SK, Brown DM. The effect of
Goldblatt hypertension on development of the glomerular lesions of diabetes mellitus in the rat. Diabetes 1978;27:738-44.

35 Brenner BM. Hemodynamically mediated glomerular injury and the progressive nature of kidney disease. Kidney Int 1983;23:647-55.

36 Parving H-H, Hommel E. High blood pressure is a major factor in progression of diabetic nephropathy. Fournal of Diabetic Complications 1988;2:92-5.

37 Bank N, Klose R, Aynedjian HS, Nguyen D, Sabtay LB. Evidence against increased glomerular pressure initiating diabetic nephropathy. Kidney In 1987;31:898-905.

38 Zatz R, Dunn BR, Meyer TW, Anderson S, Rennke HG, Brenner BM. Prevention of diabetic glomerulopathy by pharmacological amelioration of glomerular capillary hypertension. I Clin Invest 1986;77:1925-30.

39 Bending JJ, Doods RS, Walker JD, Viberti GC, Keen H. Dietary protein restriction delays the progression of diabetic renal failure. Diabetologia 1987;30:498A(abstract).

40 Parving H-H, Kastrup J, Smidt UM, Andersen AR, Feldt-Rasmussen B, Christiansen JS. Impaired autoregulation of glomerular filtration rate in Type 1 (insulin-dependent) diabetic patients with nephropathy. Diabetologia 1984;27:547-52.

41 Marre M, Leblanc H, Suarez L, Guyenne T-T, Ménard J, Passa P. Converting enzyme inhibition and kidney function in normotensive diabetic patients with persistent microalbuminuria. Br Med f 1987;294:1448-52.

42 Parving H-H, Andersen AR, Smidt UM, Christiansen JS, Oxenbøll B, Svendsen PA. Diabetic nephropathy and arterial hypertension: the effect of antihypertensive treatment. Diabetes 1983;32(suppl 2):83-7.

43 Croog SH, Levine S, Testa MA, et al. The effects of antihypertensive therapy on the quality of life. $N$ Engl f Med 1986;314:1657-64.

44 Barnett AH, Leslie D, Watking PJ. Can insulin-treated diabetics be given beta-adrenergic blocking drugs? Br Med f 1980;280:976-8.

45 Edwards CRS, Padfield PL. Angiotensin-converting enzyme inhibitors: past, present and bright future. Lancet 1985;i:30-4.

46 Roberts DH, Tsao Y, McLoughlin GA, Breckenridge A. Placebo-controlled comparison of captopril, atenolol, labetalol, and pindolol in hypertension complicated by intermittent claudication. Lancet 1987;ii:650-3.

47 Paulson DB, Jarden JO, Vorstrup S, Holm S, Godffredsen J. Effect of captopril on the cerebral circulation in chronic heart failure. Eur $\mathcal{F}$ Clin Invest 1986;16:124-32.

(Accepted 8 fune 1988)

\section{ONE HUNDRED YEARS AGO}

The ethical question how far it is pusillanimous and even religious to profit by the annihilation of pain which anaesthesia affords under surgical operation and in parturition has recently undergone discussion anew in some of the French papers. The discussion is antiquated and out of date in this country, and many of the stories told would hardly bear repetition in this serious country. Sir James Simpson long ago disposed of the argument now revivified, which charges the woman who accepts anaesthesia in childbirth with evading the Biblical injunction of pain. An indignant Frenchwoman has revived an old argument with some flippancy, but not without a reckless wit. "You quote," she says, "some verselets of the Bible against us; but let me remind you that the only one of your sex who took his part in the act of giving birth profited by anaesthesia; for when Adam gave up a rib towards the creation of Eve, he was first thrown into the deep sleep of insensibility." (British Medical fournal 1888;ii:674) 